Yıl: 23 Cilt: 23 Sayı: 2 Aralık 2021 s.220-242 Makale Türü: Araştırma

Makalenin Geliş Tarihi: 04.09.2021 Makalenin Kabul Tarihi: 30.11.2021

\title{
Uyuşmazlıkların Çözümünde Üçüncü Taraf Rolü Olarak Arabuluculuk*
}

\section{Yakup Şahin**}

\begin{abstract}
Öz: Çatışmaların çözümü zor ve meşakkatli süreçlerdir. Çatışan tarafların sorunlarını çözemediği durumlarda çatışmanın dışında olan üçüncü bir taraf müdahalesine ihtiyaç duyulur. Üçüncü taraf rolleri arasında en yaygın ve başarılı olanı arabuluculuktur. Bu çalışmada uluslararası ilişkilerde üçüncü taraf rollerinin ne olduğu ele alınacak ardından da bir üçüncü taraf rolü ve yöntemi olarak arabuluculuğa odaklanılacaktır. Arabuluculuğun uluslararası hukuktaki ve teorilerdeki yeri, tanımı, arabuluculuk süreçleri, türleri, yöntemleri ve tarihi incelenecektir. Arabuluculuğa dönük tartışmalar ve yaklaşımlar farklı pencerelerden değerlendirilecektir. Çalışmada ideal arabulucunun arabuluculukta tarafsız olması gerektiği iddiasının de facto olarak her zaman doğru olmadığı savunulacaktır. Arabuluculukta taraf ya da tarafsızlık ikileminin arabulucunun süreci yönetişi, çatışan aktörlere yaklaşımı ve özellikle gücü çerçevesinde ele alınması gerektiği iddia edilecektir.
\end{abstract}

Anahtar Kelimeler: Arabuluculuk, Üçüncü Taraf Rolü, Çatışma Çözümü, Barış Çalışmaları, Tarafsızlık, Yansızlık

\footnotetext{
* Bu makale 2019 yılında Ankara Üniversitesi Sosyal Bilimler Enstitüsü’nde tamamlanan “Kimlik Ve Dış Politika: Türkiye’nin Arap-İsrail Ve Balkan Uyuşmazlıklarına Dönük Arabuluculuk Girişimleri (2002-2016)” başlıklı doktora tezinin bir bölümünün gözden geçirilmiş halidir.

** Dr. Öğretim Üyesi, Polis Akademisi Güvenlik Bilimleri Enstitüsü, e-mail; sahinyakup33@ gmail.com, ORCID:0000-0002-4548-0277
} 
ISSN: $2148-6166$

Year: 23 Volume: 23 Issue: 2 December 2021 p.220-242 Article Type: Research Received Date: 04.09.2021 Accepted Date: 30.11.2021

\title{
Mediation as a Third Party Role in Conflict Resolution
}

\section{Yakup Şahin}

\begin{abstract}
Conflict resolution is a difficult and arduous process. When the conflicting parties are unable to resolve their problems there is a need to a third-party interventionist outside the conflict. Among the third-party roles, the most common and successful is mediation. In this study, the role of third parties in international relations will be discussed and then mediation will be focused on as a third party role and method. The place, definition, mediation processes, types, methods and history of mediation in international law and theories will be examined. Discussions and approaches about mediation will be evaluated from different perspectives.In the study, it will be defended that the claim that the ideal mediator should be impartial in mediation is not always true de facto.It will be argued that the dichotomy of party or impartiality in mediation should be addressed within the framework of the mediator's management of the process, its approach to the conflicting actors and especially its power and capacity.
\end{abstract}

Key Words: Mediation, Third Party Roler, Conflict Resulution, Peace Studies, Impartiality, Neutrality 


\section{Giriş}

Bir uyuşmazlık durumunda tarafların konuyu ele alıp çözüme kavuşturması beklenir. Ancak çatışan taraflar sorunlarını her zaman kendi aralarında çözemezler. Tarafların iletişim sağlayamadıkları ya da iletişim sağlanmışsa da görüşmelerin istenilen yörüngede olmadığı (Yılmaz, 2005, s. 125-126), çatışmanın uzadığı, çatışan tarafların yorulduğu, çatışma maliyetinin giderek artmasından dolayı tarafların çatışmadan kaçmak istedikleri buna rağmen kendi aralarındaki çatışmanın çözümüne dönük girişimlerinin başarısız olduğu durumlarda üçüncü bir tarafa ihtiyaç duyulur (Bercovitch, Anagnoson ve Wille, 1991, s. 8). Bir uyuşmazlığı aracılar yardımıyla çözmek tüm kültürlerde yeri olan bir yöntemdir. Çalışmanın ilerleyen bölümlerinde gösterileceği üzere bahsedilen üçüncü taraf rolleri içinde en yaygın ve başarılı olanı arabuluculuktur. Yapılan bir araştırmaya göre çatışmaların yüzde 70'inde arabuluculuk yöntem olarak kullanılmıştır (Bercovitch ve Jackson, 2020, s. 65-66). Ayrıca 2000’li yıllarla birlikte “uyuşmazlık çözümü ve arabuluculuk” (Dışişleri Bakanlığı, http://www.mfa.gov.tr/uyusmazliklarin-cozumu-ve-arabuluculuk.tr.mfa ) Türkiye'nin temel dış politika konularından ve dış politika araçlarından birisi haline gelmiş; buna binaen Türkiye farklı coğrafyalarda ve ülkelerde farklı seviyelerde arabuluculuk girişimlerinde bulunmuştur. $\mathrm{Bu}$ politikaya istinaden girişimlerin yanında arabuluculuğa odaklanan araştırma merkezleri kurulmuş, uluslararası kongreler düzenleniş, Dışişleri Bakanlığında Genel Müdürlük kurulmuş, İstanbul'un bir uluslararası arabuluculuk merkezi olması hedeflenmişidir (Bkz: Şahin, 2020, s. 259-303). Arabuluculuk çatışmaların çözümündeki en çok başvurulan ve en başarılı yöntemlerin başında gelmesi, Türk dış politikasındaki yeri arabuluculuğun önemini göstermektedir. Arabuluculuğun iyi anlaşılması için bu çalışmada arabuluculuğun tanımı, tarihi, rolleri, arabuluculukla ilgili tartışmalar ele alınacaktır. Bu çalışmanın, arabuluculuğun taraflı mı yoksa tarafsız mı olması gerektiği yönündeki tartışmaları ülkelerin kimlikleri, kapasiteleri ve uyuşmazlık yaşayan aktörlerle kurduğu ilişki çerçevesinde incelesi daha onu önceki çalışmalardan ayırmaktadır.

Arabuluculuk bir çatışan taraflar dışında olan üçüncü bir tarafın müdahalesidir. Arabuluculuk gibi bir üçüncü tarafa neden ihtiyaç duyulduğu, arabuluculuğun ne gibi önemi olduğu sorusuna birkaç yanıt verilebilir. Üçüncü taraf; uyuşmazlığa dönük çözümü kolaylaştırması, uyuşmazlık yaşayan aktörler (taraflar) arasında iletişim kanalları açması bakımından önemlidir (Zartman, 2001, s. 452-453). Ayrıca, uyuşmazlıkları barış̧̧ı yollar ile çözmek, silahlı yol ile müdahaleye göre daha kolay ve düşük maliyetlidir. Bu müzakere süreci her zaman sonuç getirmese de tarafların birbirini anlaması, taraflar arası iletişimi sağlaması, çatışmanın şiddetini düşürmesi gibi noktalarda katkı sağlayabilmektedir. Üçüncü taraf yapacağı müdahaleler ile sorunun çözülmesinde etkili olabilmektedir. Üçüncü tarafların müdahaleleri de her zaman uyuşmazlığı çözemeyebilir, ancak her uyuşmazlık 
çözülmese de müzakere edilebilir (Zartman ve Touval, 1996, s. 438). Böylelikle yıkıcı çatışmadan kurtulunmuş ve olası barışın önü açılmış olabilir.

\section{Üçüncü Tarafın Tarihi}

Bir üçüncü taraf girişimi olan arabuluculuğa geçmeden önce üçüncü tarafın tarihini bilmek öğretici olacaktır. Uyuşmazlıkların çözümünde üçüncü bir tarafın girişimi insanlık tarihi kadar eskidir. Ancak diplomatik anlamda M.Ö. 3000-4000 yıllarında başvurulan hakemlik günümüzdeki arabuluculuğun temeli sayılabilir (Pazarcı, 2004, s. 446). Arabuluculuğun Homeros'un İlyada Destanında (M.Ö. 750) ve Sophocles'in Ajax'ında (M.Ö.500) da vurgulandığı görülmektedir (Yıldırım, 2015, s. 28). Üçüncü tarafların diplomasi tarihinde ise 1648 'de kurulan devletler sistemi ile birlikte daha etkili olarak süreçlerin içinde yer aldıkları değerlendirilmektedir (Zartman ve Touval, 2007, s. 340). Arabuluculuk gibi üçüncü taraf rollerinin genel çerçevesi 1899 ve 1907 La Haye Uyuşmazlıkların Barış̧ı Çözümü Sözleşmeleri ve 1948 Bogota Barışçı Çözüm konusunda Amerikan Anlaşması ile uluslararası hukuk tarafından çizilmiştir (Pazarcı, 2004, s. 443-491). Ancak bu çalışmadaki anlamında kullanılması II. Dünya Savaşı sonrası kurulan düzen ile başlamaktadır. Özellikle de "Uyuşmazlık Analizi ve Çözümü, Barış Çalışmaları" Soğuk Savaş ile birlikte daha popüler hala gelmiş, siyaset bilimi ve uluslararası ilişkiler disiplinin altında bir inceleme konusu olmuştur. Önceleri kişilerarası ilişkiler ya da iş yerlerinde yaşanan uyuşmazlıkların çözümü ve yönetimi için başvurulan bir alan olmuşsa da II. Dünya Savaşının miras bıraktığı yıkım ve korku ile Soğuk Savaş gerginliği ve "dehşet dengesi”, olası bir nükleer yıkım bu alanın giderek popüler ve önemli bir hale dönüşmesine sebep olmuştur. Literatürde ABD ve İskandinav ekolü olmak üzere iki büyük ekol bulunmaktadır. ${ }^{1} \mathrm{Bu}$ çalışmanın konusu olan arabuluculuk çatışma çözümü içinde giderek gelişen bir tema olmuştur. Zor kullanama yönetime başvurmadan tarafları bir araya getiren uluslararası arabuluculuğa dönük akademik anlamdaki metinler 1960’lı yıllarda başlamış, 1980’lerde olgunlaşmış nihayetinde 2000’li yıllarda daha derinlikli bir

\footnotetext{
1 Uyuşmazlık çözümü ve barış çalışmalarının dönüşümü için bkz (Şahin,2012). Uyuşmazlık çözümü ve barış çalışmaları içinde uyuşmazlıkların çözümü daha çok uluslararası hukuk tarafından belirlenmiş, uluslararası toplum ve örgütlerin destek verdiği formal yöntemler ve süreçler olarak bilinmektedir. Çatışmaların doğasının değişmesi, çatışan aktörler ve tarafların genişlemesi devlet merkezli geleneksel yaklaşımların çatışmaları çözmekte yetersiz kalmasına neden olmuştur. Barış çalışmaları içinde dönüştürücü olarak ifade edilen çözüm yolları ise sivil toplum örgütlerinden uluslararası örgütlere, kamu diplomasisinden aktivist hareketlere devlet merkezli yaklaşımları da aşarak toplumun tüm kesimlerini içine alan yaklaşımlardır. Burada daha çok gönüllülük üzerine kurulmuş; içinde eğitimden sosyal etkinliklere kadar pek çok rehabite edici ve yeniden inşa edici yöntemi barındıran alternatif çabalar vardır denilebilir. Çatışmaların çözümü ve barışın inşasına dönük yöntemler ise çok geniştir, ekollere göre farklılık gösterebilmektedir. Ayrıca bkz.(Wallensteen 2007; Bercovitch, ve Jackson, 2020; Dizdaroğlu, 2019).
} 
hal almıştır (Kiraz, 2020, s. 228). Arabuluculuk uzun yıllar kavramsal bir belirsizlik yaşamış; tartışmalar yalnızca betimsel ve kavramsal yaklaşımlarla sınırlı kalmıştır (Bercovitch ve Jackson, 2020 s. 66).

\section{Uluslararası Hukuk ve Barış Çalışmaları Bakımından Arabuluculuk}

Yaşanan bir uyuşmazlığın çözümünde üçüncü taraf rolü çok eski tarihlere kadar gitmektedir. Bu konu özellikle İkinci Dünya Savaşı sonrası Birleşmiş Milletler sistemi içinde düzenlenmeye çalışmış, ayrıca o dönemde yeni bir alan olarak yükselen Uyuşmazlık Analizi ve Barış Çalışmalarının² içinde önemli bir yere sahip olmuştur. BM sistemi ve uluslararası hukuk çerçevesinde aşağıda değinileceği üzere Westfalyan sisteme dayanan devlet merkezli formal yollar belirtilmiştir. Uyuşmazlık Analizi ve Barış Çalışmaları ise üçüncü taraf rollerini formal yolların eksikliği ve yetersizliğinden hareketler daha geniş, yapısal ve çok aktörlü ele almıştır. Aşağıda bu yaklaşımlar daha ayrıntılı gösterilmektedir.

Uluslararası hukuk açısından bakıldığında BM Antlaşmasının VI. Bölümünün başlığı “Uyuşmazlıkların Barışçıl Çözümüdür” (BM Anlaşması, VI. Bölüm, s.1213). Bu bölümde üye devletlere uyuşmazlıkları görüşme, soruşturma, arabuluculuk, uzlaştırma, hakemlik, yargı, bölgesel örgütlere ve anlaşmalara başvurma ya da tarafların kendilerinin seçeceği başka barışçı yollarla çözmeleri gerektiği söylenmektedir. Ayrıca BM Antlaşması sayılan bu yollar dışında Güvenlik Konseyi’ni uyuşmazlıkların barış̧̧ı yollarla çözülmesi noktasında görevlendirmektedir. Pazarcı'ya göre devletlerarası uyuşmazlıkların barışçıl yollarla çözülmesi bizatihi bir zorunluktur (Pazarcı, 2004, s. 447). Uyuşmazlıkların barış̧̧ıl yollarla çözümü için üçüncü taraf rolleri geleneksel ve dönüştürücü, yani; pozitif ve normatif olmak üzere ikiye ayrılabilir. Geleneksel olarak nitelendirilen yollar daha çok BM Anlaşması ve uluslararası hukuk çerçevesinde tanımlanmıştır. Bunlar da kendi içinde yargı dışı (siyasi) ve yargısal yollar olmak üzere ikiye ayrılmaktadır. Kuvvet kullanmayı da içeren başka önlemler de bulunmaktadır. Ancak bu çalışma barış̧̧l yöntemleri incelediği için onlar çalışmanın dışındadır (Şahin, 2012, s. 39). Geleneksel çözüm yolları daha çok uluslararası hukuk kurallarınca belirlenmiş, uluslararası toplum ve örgütlerin desteklediği formal yöntemlerdir. Uyuşmazlık yaşayan aktörlerin yürütülmesinden sonlandırlmasına kadar sürecin işleyişine doğrudan karar verdikleri yargı dışı yollar görece siyasidir, bağlayıcılığı yoktur ve son kertede karar vericiler de uyuşmazlık içindeki aktörlerdir. Bu yollar, "dostça girişim, arabuluculuk, araştırma ve soruşturma, uzlaştırma" gibi üçüncü tarafların da müdahil olarak çözüm aradıkları süreçlerdir. Diğer yöntem ise üçüncü tarafların bağlayıcı karar verdikleri "uluslararası hakemlik" ile "uluslararası mahke-

\footnotetext{
2 Makalede uyuşmazlık ve çatışma birbirilerini ikame edecek anlamda kullanılacaktır. Ayrıca, İngilizcede Conflict Analyses, Conflict Resolution ve Peace Studies çalışmalarının Türkçe karşılığı Uyuşmazlık ve ya Çatışma Analizi, Barış Çalışmaları olarak çevrilecektir.
} 
meleri” kapsayan yargısal yollardır (Pazarcı, 2004, s. 447-453). Çatışmaların çok fazla şiddetlendiği, insani dramların yaşandığı, uluslararası barış ve güvenliğin tehlikeye girdiği, diplomatik girişimlerin ve diğer başka çözüm arayışlarının yetersiz kaldığı durumlarda uluslararası toplum çatışmalara müdahil olabilmektedir. Bu yollar "çatışmayı önleme, barışı koruma, barışı yapma, barışı inşa etme, insani müdahale, koruma yükümlülüğü” gibi kendi içinde şartları olan doğrudan müdahale yöntemleridir (Wallensteen, 2002; Şahin, 2012, s. 39-40). Ancak, "insani müdahale, koruma yükümlüğü" gibi konulardaki tartışmaların devam ettiği unutulmamalıdır (Keskin, 2009, s. 87-88; Sak, 2015, s.121-153). Dolayısıyla üçüncü taraf rolü arabuluculuk, kolaylaştırıcılık, uzlaştırıcılık, danışmanlık, barışı koruma ya da tahkim olabilir (Kiraz, 2020, s.228). Bu makalede ise sadece bir üçünde taraf rolü olan "arabuluculuk” üzerinde durulacaktır.

Yukarıda değinildiği üzere uyuşmazlıkların çözümünde doğrudan uluslararası hukukun konusu olmayan yeni yollar daha çok uyuşmazlık/çatışma analizi ve barış çalışmalarının konusudur. ${ }^{3}$ Geleneksel çatışma çözümü yaklaşımlarında daha çok arabuluculuk bu çerçevede değerlendirilmiş olsa da Soğuk Savaş sonrası dönemde yeni bir dönüşüm yaşanmaktadır. Bu dönüşüm ileride daha ayrıntılı anlatılacağı için tekrara düşmemek adına burada değinilmeyecektir.

Uyuşmazlık analizi ve barış çalışmaları içindeki dönüştürücü olarak da tanımlanan çözüm yolları ise toplumumun tüm kesimlerini, sivil toplum örgütlerini, uluslararası örgütleri, kamu diplomasisini, aktivist hareketleri kapsayan, eğitimden sosyal etkinliklere kadar pek çok rehabilite ve yeniden inşa edici yöntemi içinde barındıran, uyuşmazlığın kökeninde bulunan sorunların ortadan kaldırılmasına dönük yapısal çözümleri içine alan gönüllülük üzerine kurulmuş alternatif girişimlerdir. İçerisinde yapısal unsurlarla birlikte üçüncü taraf rolleri de vardır (Şahin, 2012, s. 39-40). ${ }^{4}$ Uyuşmazlığa neden olan sorunların çözümünün daha kalıcı barış getireceğine inanılır. Bu noktada psikoloji, sosyoloji, ekonomi, siyaset ve hukuksal önlemler ve yollar birlikte değerlendirilir. Yani uluslararası hukuku kapsayan hatta onun tıkandığı yerlerin farkına varıp, ötesine geçen bir takım faaliyetlerdir.

Uyuşmazlık analizi ve çözümü bağlamında üçüncü taraf rolleri ve arabuluculuk konusunda hala derin tartışmalar yaşanmaktadır. ${ }^{5}$ Yıldırım (2015) tarafından Bercovitch ve DeRouen'e atıfla çatışma analizi ve çözümü açısından yaşanan bir uyuşmazlık "uzlaştırma, hakemlik ve yargı, danışma ve problem çözme, barış gücü kullanımı, arabuluculuk” yöntemi olarak sınıflandırılmıştır (s. 33-34). Beriker (2014) ise, üçüncü tarafların rollerini "kolaylaştırıcllık, güçlü arabulu-

\footnotetext{
3 Burada alt çizilmesi gereken nokta; yeni yolların uluslararası hukuk dışında ya da ona karş1 bir arayış olmadığıdır. Çatışmaların çözümündeki yeni arayışlar ve girişimler uluslararası hukuk yollarını da kapsayan hatta onun ötesine geçen bazı arayış ve girişimlerdir.

4 Daha ayrıntılı bilgi için bkz. (Wallensteen, 2007; Mial, Ramsbotham ve Woodhouse, 2007).

5 Bakınız: (Jeong, 2009; Moore, 2003 ; Beardsley, Quinn, Biswas ve Wilkenfeld, 2006, s. 58-86; Touval, 2003, s. 91-95; Zartman, 2013, ss. 13-25; Duursma, 2014, s. 81-98; Fisher, 2001, s. 1-27.
} 
cu, barışı koruyucu, barışı zorlayıcı” (s. 202) olarak kategorize etmiştir. Aşağıda hem uluslararası hukuk hem de yeni tartışmalar bağlamında arabuluculuk ile ilgili genel konulara değinilecektir. Yeni çalışmalarla birlikte arabuluculuğun tanımı, yöntemi ve arabulucuya dönük beklentiler dönüşmüştür.

\section{Arabulucunun Kimliği ve Arabulucuya İlişkin İstatistikler}

Arabulucular kişiler, devletler, uluslararası örgütler ya da sivil toplum kuruluşları olabilir (Bercovitch ve Jackson, 2020, s.75-81). Üçüncü bir tarafın müdahalesi bazen davet bazen de ilgili üçüncü tarafın girişimi ile olabilmektedir (Jeong, 2009, s. 221-216).6 Daha önce değinildiği üzere Soğuk Savaş sonrası dönemde çok aktörlü arabuluculuk süreçleri daha yaygın hale gelmiştir (Kiraz, 2020, s. 228). Soğuk Savaş sonrası dönemde özellikle artan iç çatışmalar ve küreselleşme süreci arabulucuların devletler ya da uluslararası örgütlerin ötesinde yeni aktörler daha aktif oldukları görülmektedir.

1946-2000 yılları arası yaşanan uyuşmazlıkların çözümüne uluslararası örgütler 620 defa, devletler 433 defa, koalisyon halindeki devletler 99 defa, sivil toplum örgütleri ise 49 defa müdahil olmuştur. Kimi kaynaklara göre ise 19451995 yılları arasındaki 2194 arabuluculuktan 855'i devletler, 648'i uluslararası örgütler, 321'i bölgesel örgütler, 87'si sivil toplum örgütleri tarafından yapılmıştır (Bercovitch ve Fretter, 2007, s. 145-173). 1919 -1965 yılları arası 95 uluslararası uyuşmazlığın 45 tanesine üçüncü bir taraf arabulucu olmuş, bu müdahilliklerden 30 tanesi başarılı olmuştur. Yapılan bir araştırma sonucuna göre de 1950 ile 1990 yılları arası yapılan arabuluculukların yüzde 36'sının başarılı olduğu iddia edilmektedir. Bu arabuluculukların yüzde 49,10'u devlet, yüzde 37,62'i uluslararası örgüt, 4,01’i Hükümet Dışı Örgütler, yüzde 5,26’sı bireyler, geriye kalanlar ise karışık koalisyonlar tarafından yapılmıştır. Devletlerin ve uluslararası örgütlerin daha aktif ve etkili oldukları görülmektedir (Bercovitch ve Schneider, 2000, s. 145-165). Başka bir kaynakta ise 1945-2000 yılları arasında yaşanan uyuşmazlıkların yüzde 58'inde arabuluculuk, yüzde 33'ünde görüşmeler, yüzde 1'e yakınında hakemlik yoluna başvurulduğu belirtilmektedir (Yıldırım, 2015, s. 121).7

\section{Arabuluculuğun Tanımı}

Geleneksel uluslararası ilişkiler çalışmalarında arabuluculuk uluslararası uygulamalardan doğmuş, 1899 ve 1907 La Haye Uyuşmazlıkların Barışçı Çözümü Sözleşmeleri ve 1948 Bogota Barışçı Çözüm Konusunda Amerikan Anlaşması ile kısmen de olsa düzenlenmiştir (Pazarcı, 2004, s. 447-453). BM Genel Kuru-

\footnotetext{
6 1946-2000 yılları arası hükümetler arası örgütler 620 kez, devletler 433 kez, koalisyon halindeki devletler 99 kez, NGOlar 49 kez müdahil olmuştur (Frazier ve Dixon, 2007, s. 388-389).

7 Ayrıca benzer tartışmalar için bkz. (Aktaş, 2014; Alpay ve Tanmaz, 2015).
} 
lu’nun 65/283 sayılı “Uyuşmazlıkların barışçıl çözümü, çatışmanın önlenmesi ve çözümünde arabuluculuğun rolünün güçlendirilmesi” başlıklı kararı arabuluculuğu "Üçüncü bir tarafın, iki ya da daha çok tarafa, kendi rızalarıyla, bir çatışmayı önlemek, yönetmek ya da çözmek için, karşılıklı kabul edilebilir mutabakatlar geliştirmelerine yardım ederek yardımcı olduğu bir süreç.” (BM Genel Kurul, 2012) olarak tanımlanmaktadır. Uluslararası hukuktaki genel kabule göre arabuluculuk üçüncü bir devlet, örgüt ya da nadiren de olsa bireyin; uyuşmazlığın çözümüne katkı sağlamak adına uyuşmazlığın tarafları ile görüşmesi, görüşmelere katılması ya da onları sürece ikna etmesi olarak değerlendirilmektedir (Zartman ve Touval, 2007, s. 437-438). Arabuluculuk ile dostça girişim karşılaştırıldığında arabuluculuğun dostça girişime göre daha aktif bir süreç olduğu söylenebilir (Pazarcı, 2004, s. 447-456; Gürkaynak, 2009, s. 129-132). Fakat son dönemlerde yeni yaklaşımlara göre arabulucu birey, devlet, uluslararası bir örgüt ya da NGO (devlet dışı örgüt) olabilir.

Her ne kadar yukarıda BM’nin arabuluculuk tanımı gösterilmiş olsa da akademik literatürde arabuluculuğun tanımı konusunda farklı görüşler bulunmaktadır. Mevcut uluslararası düzende arabuluculuk, kökleşmiş, çözümsüz olarak kabul edilen sorunların çözümünde bölgesel ve uluslararası düzenin inşasında önemli bir araç olarak görülmektedir (Bercovitch, 2002, s. 4). Ancak üçüncü taraf rolleri ve arabuluculuğun şekli, türleri ve hatta tanımında farklılıklar bulunmaktadır. Örneğin, kimi uzmanlar arabuluculuğu, müzakereye başlamanın bir adım öncesi olarak değerlendirirken kimi uzmanlar doğrudan sürecin içinde bulunup müdahil olma, ya da süreç sonrası iletişim olarak da görebilmektedirler. ${ }^{8}$ Arabulucu iletişim yollarını açıp, uyuşmazlık yaşayan iki tarafın birbirlerini hukuken olmasa da siyaseten fiili olarak tanıyıp iletişim kurmalarını hatta bazen meşru kabul etmelerini sağlayan, müzakere sürecinin ilerlemesini kolaylaştıran, taraflara seçenekler sunabilen, tarafları, gerek eksikleri konusunda gerekse gerçekçi ve ulaşılabilir hedefler konulması konusunda uyaran ve yeri geldiğinde de müdahale edip yönlendirebilen aktör olarak da nitelendirilmektedir. Bu yaklaşıma göre arabuluculuk taraflara dayatma ya da zorlama yapmadan kendi aralarında bulamadıkları çözüm için bir tür üçüncü taraf mücadelesini içeren politik bir süreç olarak da görülebilir (Moore, 2003, s. 19-20; Yıldırım, 2015, s. 28-32) Arabuluculuğa dönük bir başka tanımlama ise iki ya da daha çok taraf arasında yaşanan bir uyuşmazlığın çözülebilmesi için uyuşmazlığın doğrudan tarafı olmayan bir aktörün müdahil olarak, sorunun çözümüne dönük arayış süreci olduğudur. ${ }^{9}$

Literatürde arabuluculuğun da içinde olduğu yargı dışı uluslararası hukukun belirttiği üçüncü taraf rolleri konusunda çok açık ve net ifadeler olmadığı görülmektedir. Bu noktada kolaylaştırıcılık, dostça girişim ve arabuluculuk birlikte değerlendirilmekte olup aralarındaki temel farklılık yöntemleridir. Ayrıca dostça

8 Bkz. (Bercovitch, 2004, s. 24).

9 Ancak ileride gösterileceği üzere kimi uzmanlar uyuşmazlığın doğrudan ya da dolaylı taraflarının da zaman içerisinde arabulucu olabildiklerini iddia etmektedirler (Powell, 2014, s. 183). 
girişim ile kolaylaştırıcılığı arabuluculuğun altında değerlendiren isimlerin olduğu da akılda kalmalıdır (Pazarcı, 2004, s. 448-452). Jacob Bercovitch arabulucuyu uyuşmazlık yaşayan tarafların kendilerine psikolojik, fiziksel, hukuki zorlama ve baskı yapmadan aralarındaki sorunu çözme noktasında yardımcı olmak için davet ettikleri, bir nevi uyuşmazlık yönetimi süreci olarak değerlendirirken (Jönsson, 2000, s. 21), William Zartman arabuluculuğun hakemlik ve yargı yollarından ayrllan üçüncü taraf müdahalesi olduğunu belirtmektedir. Zartman'a göre arabuluculuk diğer ü̧̈üncü taraf girişimleri gibi görülse de son karar verici uyuşmazlık yaşayan taraflar olduğu için farklılık arz eder; çünkü son noktada kararlar uyuşmazlığın taraflarınca verilecektir (Fisher ve Keashly, 1991, s. 33). Arabulucu, tarafların üzerinde uzlaşamadığı konuları yeniden tanımlar, yeni alanlar ve temalar belirleyerek sürecin tıkandığı zamanlarda yeniden başlayarak devam etmesini sağlar. Tarafları beklentileri, sürecin olumlu ya da olumsuz sonuçları, hedeflere ulaşılabilirlik konusunda uyararak yönlendirir (Bercovitch, 1992, s. 17-18). Dolayısıyla kolaylaştırıcılık, paralel diplomasi, sorun çözme çalıştayları da arabuluculuğun türevleri arasında sayılabilmektedir (Çuhadar, 2009, s. 131).

Ancak kimi uzmanlar arabuluculuk ile kolaylaştırıcılığın karıştırılmaması gerektiğini savunmaktadırlar. Çünkü üçüncü taraf olma, tavsiyelerde bulunmaktan baskı yaparak tarafları ikna etmeye kadar uzanan bir içeriğe sahiptir. Ancak bazı uzmanlar kolaylaştırıcılığı arabuluculuk çatısı altında değerlendirmektedir (Çelik, 2015, s. 17). Hatta ileride de gösterileceği üzere arabuluculuk kategorize edilirken "kolaylaştırıcı arabuluculuk" da eklenmiştir (Zartman ve Touval, 2007, s. 437-454; Touval ve Zartman, 2001, s. 427-443). Literatür ise kolaylaştırıcillğı uyuşmazlığın içeriğine doğrudan müdahale etmek yerine uyuşmazlık yaşayan tarafların iletişim kurmalarına ve müzakereleri kolaylaştırıcı adımlar atılmasına katkı sağlayan girişimler olarak tanımlamaktadır (Çuhadar, 2009, s.135; Snodderly, 2011, s. 23).

Yukarıda da gösterildiği üzere arabuluculuk bir uyuşmazlıkta taraflar üzerinde hukuki yetkisi olmadan, gönüllülük üzerine kurulmuş bir üçüncü taraf müdahalesidir(Yılmaz, 2005, s. 128; Bercovitch ve Derouen, 2004, s. 152-153). Ancak her ne kadar arabulucunun taraflar üzerinde hukuki otoritesi olmasa bile arabulucunun gücü, ilişkileri, taraflar üzerindeki etkisi sürecin yürütülmesinde belirleyici olabilmektedir. Arabuluculuğun diğer üçüncü taraf müdahalelerinden farkı, bir tarafın kazanması için güç kullanmamayı ya da başka araçlarla müdahale etmemeyi gerektirmemektir. Bağlayıcılığı olmaması arabuluculuğu hakemlikten ayırmaktadır (Zartman ve Touval, 2007, s. 338-340).

Çatışmalar Soğuk Savaş sonrası dönemde daha çok devletlerarası savaşlardan, etnik temelli çatışmalara, iç savaşlara, terörizme, ayrılıkçı harekete dönüşmüştür. $\mathrm{Bu}$ arabuluculuğa da yansımıştır. Soğuk Savaş öncesi dönemde daha çok uluslararası çatışmaların görülmesinin bir yansıması olarak uluslararası arabuluculuk yaygınken, Soğuk Savaş sonrası dönemde ülke içinde yaşanan çatışmalara dönük arabuluculuk faaliyetleri daha fazladır (Kiraz, 2020, s. 236; Bercovitch 
ve Jackson, 2020, s. 66-69). Ancak bu noktada devlet egemenliği, çatışan devlet dışı bir aktörün tanınma ve tanınmama, taraf kabul edilmesi, Westfalyan devlet egemenliğinin erozyona uğraması gibi tartışmalar gündeme gelmeye başlamıştır. Arabulucular ya da arabuluculuk süreçleri de dönüşmüştür.

Zor kullanma dışındaki gibi üçüncü taraf rollerinin, özellikle de arabuluculukta çatışan tarafların rıza göstermesi ve ilgili aktörü kabul etmesi hayati role sahiptir (Jeong, 2008, s. 211; Çelik, 2015, s. 215-216). Rıza ise birden çok etken üzerinden sağlanabilir. Arabulucu sorunu çözebilmek için uzmanlığa, statüye, siyasi ve ekonomik güce (Yılmaz, 2005, s. 128-129), ödül, sembol, baskı ve zor, meşruiyet, bilgi ve uzmanlık (Yıldırım, 2015, s. 79 ; Bercovitch, 1992, s. 19-21), saygınlık, tecrübe gibi öğelere sahip olmalıdır (Bercovitch ve Jackson, 2020, s.72). Ayrıca arabulucunun dürüst, güvenilir ve adil olarak algılanması ile bu yönde bir imaja sahip olması da çok önemlidir. Arabulucu tarafları gücü ile etkileyebilmektedir; bu güç bazen baskı yapma, cezalandırma olabilirken bazen de ödüldür. Ancak her ne kadar arabulucunun gücü genelde ödül ya da ceza üzerine kurgulanmış gibi görülse de arabulucunun çatışan tarafları ikna edebilmesi, çatışmanın neden olacağı yıkım yerine barışın getireceği düzen ve istikrar konusunda inandırıcı olabilmesi de bir güç unsuru olarak değerlendirilebilir. Bu çalışmada üçüncü tarafların uyuşmazlık yaşayan tarafları "ödül-ceza” ya da tarafsız, adil olma dikotomisi ile ikna ettiği üzerinde durulacaktır.

\section{Arabuluculuğun “Tarafı”}

Uyuşmazlık çözümünde arabulucunun nasıl olması gerektiği, rolü ve sınırları konusunda üzerinde uzlaşılmış net bir anlayış bulunmamaktadır. Bu yüzden daha çok arabulucunun uyuşmazlık yaşayan taraflarla kurduğu ilişkilere, arabuluculuk sürecindeki rolüne, tavrına ve yönetimine odaklanılmaktadır (Stedman, 1999, s. 341). Geleneksel uluslararası ilişkiler çalışmalarına göre arabulucunun tarafsız olması beklenilmektedir. Ancak uygulamada arabulucuların her zaman tarafsız olmadıkları görülmektedir. Zaten literatür içindeki ana tartışmalardan bir tanesi arabulucunun taraflı mı yoksa tarafsız mı olması gerektiğidir. Bu konudaki tartışmalar hem akademisyenler hem de uygulayıcılar tarafından hararetli biçimde sürdürülmektedir. Bahsedilen yoğun tartışmalara karşı Bercovicth ve Schneider (2000) gibi isimler arabuluculuğun taraflı mı yoksa tarafsız mı yapılmasının daha verimli olduğu yönünde net bir çıkarım yapmanın zor olduğunu iddia etmektedirler (s. 146). Aşağıda taraflı ya da tarafsız arabuluculuğa dönük varsayımlar tartışlacaktır.

BM’nin yayınladığı Etkili Arabuluculuk Rehberinde arabulucunun tarafsızlığı ile ilgili olarak: "Tarafsızlık arabuluculuğun temel taşıdır. Bir arabuluculuk süreci önyargılı olarak algılanır ise, bu durum uyuşmazlığı çözmeye yönelik anlamlı bir ilerlemeyi sarsabilir. Bir arabulucu bütün aktörlere adil bir şekilde davranan 
dengeli bir süreç yürütmeli ve arabulucunun sonuca ilişkin herhangi bir maddi çıkarı olmamalıdır. Bu aynı zamanda arabulucunun uyuşmazlı̆̆ın çözümü ile ilgili olan bütün aktörlerle görüşebilmesini gerekli kılmaktadır. Tarafsızlık, yan tutmamakla eşanlamlı değildir, bir arabulucu, özellikle bir Birleşmiş Milletler arabulucusu, genel anlamda belirli evrensel ilke ve değerleri uygulamakla görevlidir ve arabulucunun bu ilke ve değerleri taraflara açık bir şekilde bildirmesi gerekebilmektedir."10 İfadeleri yer almaktadır. Burada vurgulanan nokta arabuluculuğun adil, çıkar gözetmeksizin yapılması gerektiğidir. Bahsedilen tanıma göre tarafsızlık, taraf tutmamakla aynı anlamda değildir; bununla birlikte süreç içerisinde adil olunması çok önemlidir. Ayrıca, BM Arabuluculuk Rehberinde arabulucunun "hazırlıklı olma, rıza, tarafsızlık, kapsamlılık, sürecin sahiplenilmesi, uluslararası hukuk ve normatif çerçeveye uygunluk, arabuluculuk çabaları arasında tutarlılık, koordinasyon ve tamamlayıcılık ve nitelikli barış anlaşmalarının oluşturulması” noktalarında hassas olması ve ilgili hassasiyetlere dikkat etmesi gerektiği de savunulmaktadır.

Çatışma Analizi ve Barış Çalışmaları literatürü incelendiğinde kolaylaştırıcılık ya da arabuluculuk konusunda tarafsızlık, nötr olma, tüm taraflara güven verme, yansız olma gibi kavramların çokça kullanıldığı görülmektedir. Çünkü genelde arabulucunun uyuşmazlık yaşayan taraflarca adil, tarafsız ve güvenilir olması beklenilmektedir. Tarafsız (impartiality) ile yansız/nötr (neutrality) ${ }^{11}$ olma kavramları sıklıkla birbirini ikame edecek şekilde kullanılıyor olsa da tarafsızlık üçüncü tarafın uyuşmazlık yaşayan taraflardan birine dönük daha olumlu ve kayırıcı eğilimleri olmaması için kullanılmaktadır. Nötr olmaktan kastedilen ise uyuşmazlık yaşayan taraflara karşı eşit ve önyargısızlıktır. Burada güvenilirlik, yansızlık gibi nitelemelere de sıkça atıf yapılmaktadır (Yıldırım, 2015, ss. 99-100).

Çatışma analizinde olduğu gibi çatışma çözümünde de "algılar” önemli bir yere sahiptir. Kimi kaynaklarda tarafsızlığın aslında bir nevi algı sorunu olduğu iddia ediliyorsa da (Yıldırım, 2015, s. 100-101) arabulucu-taraf ilişkisinin yansımaları süreç içerisinde ve sonrasında çok bariz biçimde görülebilmektedir.

Tarafsız Arabulucu: Geleneksel literatürde arabulucunun tarafsız, adil, uyuşmazlık yaşayan tüm aktörlere eşit mesafede duran ve sürece çok fazla müdahale etmeyen üçüncü taraf olarak gösterildiğine değinilmişti. Tarafsız arabulucuların her zaman özel bir yeri olduğunu iddia eden Svenson, özellikle de müdahalenin çok gerekmediği süreçlerde tarafsız arabulucunun daha da elzem olduğunu savunmaktadır (Svensson, 2006, s. 20). Young (1967) tarafsızlığın arabuluculuğun kalbi olduğunu iddia ederken (1967, s. 81) Jackson, Donelan, Duncan gibi isimler nötr olmayı ön plana çıkarmaktadırlar (Bercovitch ve Schneider, 2020, s.

\footnotetext{
10 “Birleşmiş Milletler Etkili Arabuluculuk Rehberi”, Dışişleri Bakanlığı, https://www.mfa. gov.tr/site_media/html/uyusmazliklarin-cozumu-ve-arabuluculuk/Ek-1-BM_Etkin_Arabuluculuk_Rehberi_Turkce.pdf (erişim tarihi 11.03.2020)

11 Tarafsızlık ve nötr kavramları Türkçe'de karıştırılabilmektedir. Kavramların daha iyi anlaşılması adına İngilizce literatürdeki karşılıkları da yazılmıştır.
} 
148-150). Tarafsız bir arabulucu uyuşmazlık yaşayan tüm aktörlere güven vermek ve denge tutturmak zorundaymış gibi görünse de arabulucunun da kendine ait duruşu ve politikaları olabilmektedir. İlgili uyuşmazlıktan etkilenmeyen ya da doğrudan çıkarı olmayan, dış politikada büyük hırsları olmayan devletler ile küçük ölçekli devletler daha çok tarafsız arabulucu kategorisine girmektedirler. ${ }^{12}$ Tarafsız bir üçüncü taraf uyuşmazlık içindeki aktörlerin beklentileri ya da müzakereden alınacak sonuçlarına pek fazla odaklanmaz. Arabulucunun daha çok tarafsız; partizan olmayan, uyuşmazlıktan doğrudan çıkarı ve etkisi olmayan bir üçüncü taraf olması gerektiği yönündeki yaklaşımlara değinilmişti (Svensson, 2006, s. 12). Ancak artık çatışma çözümlerinde, etkilenmiş ya da çıkarı olan arabulucuların daha aktif oldukları görülmektedir. Çatışmadan etkilenen ya da çıkarı olan arabulucular tarihsel ilişkileri ve çıkarlarından dolayı süreçlere ve taraflara önyargılı yaklaşabilmektedirler. Taraflı bir arabulucunun sürece ve uyuşmazlık yaşayan aktörlere güven veremeyeceği ve ona karşı ön yargılar olduğu için sürecin ilerleyemeyeceği savunulmaktadır. Fakat literatür artık giderek uyuşmazlıktan etkilenen ülkelerin daha etkili oldukları yönündedir. Aşağıda taraflı arabuluculara dönük tartışmalar ele alınacaktır.

Taraflı ve Etkili Arabulucu: Geleneksel yaklaşımlara göre arabulucular, tarafsız ve sürece çıkar odaklı bakmayan ülkeler olarak gösterilmektedir. Yukarıda değinildiği üzere arabulucunun mutlaka tarafsız olması gerektiğinin altını ısrarla çizmektedirler. Ancak fiili uygulamalara bakıldığında olması gerektiğini belirten normatif literatürün aksi durumların yaşandığı sıkça görülür. Zaten bu noktada arabulucunun taraflı olması gerektiğini savunan ve giderek daha çok kabul gören geniş bir kesim bulunmaktadır (Smith, 1985, s. 371). Hatta sadece arabuluculuk için değil dostça girişim, kolaylaştırıcılık gibi üçüncü taraf barış girişimlerinde da tarafsızlığın önemli olduğu söylenmesine rağmen uygulamada durumun farklı olduğu görülebilmektedir. Üçüncü taraflar uyuşmazlık yaşanan bir tarafa tarihsel bağlardan müttefiklik ilişkisine, iç politikadan ortak çıkar tanımlarına kadar farklı nedenlerden ötürü daha yakın olabilmektedir. ${ }^{13}$ Arabulucunun taraflı olması gerektiği yönündeki tezler çatışan tarafların biri ile iyi ilişkilerinin yaratacağı hareket alanı, ikna edebilme yeteneği, baskı uygulayabilmesi ve sürecin içine çekebilmesi gibi ögeler üzerine yoğunlaşmaktadır (Kydd, 2003, s. 579-611). Arabulucunun bir tarafa yakın olması beraberinde ondan taviz koparabilmeyi getirmektedir. Taraflı arabulucu yakın olduğu tarafa söz geçirerek etki altına alabilmekte ve baskı yapabilmektedir (Touval ve William Zartman, 1985, s. 15). Arap-İsrail görüşmelerinde

12 Devletlerin arabuluculuk motivasyonları farklı nedenlere dayanmaktadır.

${ }^{13}$ ABD'nin Dayton ve Camp David'de arabulucu olmasına rağmen tarafsız olmaması bu durumun en bilinen örnekleridir. ABD İsrail ile stratejik ilişkilere sahip olsa da Camp David sırasında tutum ve davranışı göreli olarak birbirinden ayırmıştır. İki tarafında sürece eşit katılmalarına özen gösterilmiş, arabuluculuk ekibi oluştururken uzmanların içinde iki tarafa da yakın isimlerin aynı sayıda olmasına özen gösterilmiştir (Çuhadar, 2009, s. 129-132). Daha ayrıntılı bilgi için bkz. (Goetschel, 2011, s. 312-333; Mayer, 2004). 
İsrail'i sadece ABD'nin ikna edebilecek olması ya da ABD'nin Dayton sürecinde Boşnaklarla yakın ilişki içinde olmasına rağmen Sırpları tehdit ederek "ikna" etmesi bu durumun örnekleri olarak gösterilebilir J. Powell (2014) ${ }^{14}$ arabulucunun asla tarafsız olamayacağını iddia etmektedir. Hatta Powell'e göre arabulucular tarafsız olduklarını iddiasıyla sadece dinleyici oldukları durumlardan çıkmalı, fikir üreterek süreçleri bir sonraki aşamaya taşımalıdır. Bu bakışa göre arabulucu yeri geldiğinde masaya yumruğunu vurabilmelidir (2014, s. 175-207).

Orta Yolcu Bakış: Bir başka yaklaşım ise orta yolcu kabul edilebilir; taraf ya da tarafsızlıktan ziyade sürecin yürütülmesine odaklanmaktadır. Bu yaklaşıma göre arabulucunun tarafsızlığı her zaman önemli olmayabilir. Kritik olan şey arabuluculuğun tarafsızlığı yerine müzakerelere sunduğu katkı, taraflarla kurduğu ilişki ve sağladığı iletişim, sürecin yönetimi ve tavırlarıdır. Hatta arabulucunun geçmişte uyuşmazlık yaşayan taraflarla iyi ilişkilere sahip olup olmaması da etkili olabilmektedir. Ancak bu tarafsızlık da sınırsız değildir, arabuluculuk sürecince tarafsızlık tamamen uzak olma anlamına gelmeyebilir (Zartman ve Touval, 2007, s. 442-443). Arabulucu yeri geldiğinde sürece zarar veren aktörleri eleştirebilir, ancak burada tarafsızlığın dengesi iyi sağlanmadır (Çuhadar, 2009, s. 204-205). Ayrıca bir taraf ile kurulan yakın ilişki sonucu diğer taraf arabulucuya önyargılı yaklaşabilir ya da güven kaybı yaşayabilir (Savun, 2008, s. 28). Bu durumu arabulucunun sunacağı şeyler önyargıyı elimine edebilmektedir.

Sonuç olarak her ne kadar geleneksel literatürde ideal arabulucunun "tarafsız" olması gerektiği söylense de gerek uygulamada gerekse de yakın dönem çalışmalarda tarafsızlığın tek başına en belirleyici kriter olmadığı söylenebilir. Buradaki önemli nokta arabulucunun süreci yönetirken nötr olabilmesi, iki tarafa da eşit ve adil davranıp güven verebilmesidir. Hatta taraf olması iyi ilişki içinde olduğu tarafı ikna edebilmesi bakımından önemlidir. Ancak başka bir kritik noktayı da gözden kaçırmamak gerekmektedir: Arabuluculuk tartışması sadece taraf ya da tarafsız olmaktan ziyade arabuluculuk stratejisi ve arabuluculuk türü başka bir ifade ile arabulucunun imkanları, gücü, etkisi ile doğrudan bağlantılıdır. Arabulucu ödül ve ceza yöntemiyle tarafları bir anlaşmaya ikna edebilmektedir. İlerleyen bölümlerde bu konu daha ayrıntı işlenecektir.

Bu noktada belirtilmelidir ki, yeni yaklaşımlar zor(ceza) ve ödül çerçevesinde yapılmış bir anlaşmanın uzun soluklu olmayabileceği uyarısında bunmaktadırlar (Kiraz, 2005, s. 231). Zor ve ödül çerçevesinde yapılan anlaşmalar çatışmaların kökeninde yatan temel nedenlere dönük çözüm önerileri getirmek yerine kısa vadeli ve devam eden çatışmaları bitirmeye dönüktür. Ancak günü kurtarmaya dönük kısa vadeli durdurulmuş ve dondurulmuş uyuşmazlıklar ilerleyen dönemde yeni çatışmalara dönüşebilmektedir (Kiraz, 2005, s. 230). Bu minvalde çatış-

14 Jonathan Powell İngiltere'nin IRA ile yaptığı barış sürecinde İngiltere'nin baş müzakerecisi ve Tony Blair'in başdanışmanı olarak göre almıştı. Powell, Inter Mediate isimli sivil toplum kuruluşunu kurmuş, bu düşünce kuruluşu aracılığı ile dünyanın farklı bölgelerinde yaşanan çatışmaların çözüme kavuşması için danışmanlık ve arabuluculuk yapmaktadır. 
ma çözümünde İskandinav ekolü ve yeni yaklaşımlar çatışmaları doğuran temel nedenlerin ortadan kaldırılmasına odaklanır. Çünkü çatışmaya yol açan öğelerin varlığı barışın kalıcı olmasını engeller, çatışmaları yeniden hareketlendirebilir. Bu yüzden yeni yaklaşımlarda barışın sağlanmasında sadece devletin resmi karar vericileri ve diplomatlar değil, toplumun farklı kesimlerinin süreç içerisine dahil edilmesi beklenmektedir (Kiraz, 2005, s. 230).

\section{Arabuluculuk Türü ve Yöntemi}

Her uyuşmazlık nevi şahsına münhasırdır; dolayısı ile de arabuluculuğun türü, şekli ve stratejileri her örnek olaya göre değişebilmektedir. Her ne kadar her olayın kendine özgün şartlara göre değerlendirilmesi gerekse de uyuşmazlıkların çözümünde ortak noktalar da bulunmaktadır.

Literatür tarandığında üçüncü taraf rolü olarak arabulucunun daha çok, kolaylaştırıcı, plan yapıcı ve güçlü, ${ }^{15}$ güçlü sade (Jönsson, 2000, s. 21), iletişimci, formül-çözüm üretici ve manipülatör (Touval ve I Zartman, 1989, s. 117), defansif ve yayılmacı (Kleiboer, 1996, s. 360-390), partizan (Koopmans, 2018, s. 128130), uzlaştırıcı, danışman, sade(pure) ve güçlü (muscle) (Greig ve Diehl, 2012, s. 7-9) gibi nitelemelerle sınıflandırıldığı görülmektedir. Ancak arabuluculuğun teknik ayrıntılarla çizilmesi, şablonlara ayrılması ya da sınırlandırılması politik bir mesele olduğu için bu tür sınıflandırmalar kimi uzmanlarca eleştirilmektedir.

Kriesberg (1996), Keashy ve Fisher (1996) gibi isimler arabulucuların oynayacağı rolün uyuşmazlığın türüne ve aşamasına göre değişebileceğini iddia etmektedirler. Yani arabuluculuğun tarzı, stratejileri örnek olaylara göre değişebilmektedir. Bu durumda süreç yönetimi, adil ve eşit olma, kaynak ve imkânlar, vaatler, tarafların tutumları gibi çok sayıda faktörün belirleyici olduğu söylenmedir. Yaşanan bir çatışmada, tarafların tutumu, taraflar ile kurulan ilişkiler önemli değişkenlerdir (s. 235-261). Zartman ve Touval (2007), gibi isimler arabulucunun uyuşmazlık çözümünde önemli rolü olduğunu da hatırlatarak arabulucunun her zaman sabit bir rolde olmayacağını, uyuşmazlığın ya da müzakere sürecinin gidişatına göre farklı rollere bürünebileceğini, farklı tarzlarda arabuluculuk yapabileceğini iddia etmektedirler (ss. 437-445). Kimi isimler arabulucunun süreç içindeki girişimlerine göre kategorizasyon yapılmasına karşı çımmaktadırlar. Bu bakış yapısal reformlar, iletişim yollarının açılması, güven artırıcı önlemlere ağır-

15 Kolaylaştırıcı arabulucu, sorunun içeriğine dönük müdahalelerden ziyade müzakere sürecini kolaylaştırmaya ve tarafların çözümlerini kendilerinin bulmalarına dönük arabulucudur. Kolaylaştırıcı arabuluculukta taraflara müzakere ortamı sunulur, kolaylaştırıcı kaynaklar ve güven artırıcı önlemlere ağırlık yapılır. Plan yapıcı arabulucu ise iletişim ve süreci kolaylaştırmaya dönük adımların ötesinde tarafların kabul edebileceği çözümler önerip müzakereleri planlar. Güçlü arabulucu süreçteki en aktif arabuluculuk türüdür. Diğer iki arabuluculuğun ötesinde kendi planının kabul edilmesi ve anlaşmaları için güç uygular. Bu baskı sahip olduğu kaynaklara göre ödül ya da ceza olabilmektedir (Çuhadar 2009, s. 135; Beriker, 2009, s. 10-11). 
lık vermektedir(Keashly ve Fisher, 1996, s. 235-261). Yukarıda bahsedilen arabuluculuk sınıflandıranlarının daha iyi anlaşılması adına kısa da olsa değinmekte fayda vardır.

Ronald J. Fisher ve Loraleigh Keashly arabuluculuğu "güçlü arabuluculuk ve "sade arabuluculuk" olmak üzere, ikiye ayırmaktadırlar. Sade arabuluculuk daha çok uyuşmazlık içindeki tarafların iletişimi, iknası ve çözüm için farklı alternatiflerin sunulmasını kapsarken güçlü arabuluculukta zorlama, baskı ve ödüllendirme gibi yöntemler bulunmaktadır (Jönsson, 2006, s. 21). Güçlü arabulucu ödül ve ceza(havuç-sopa) ile tarafları masaya oturtabilir, anlaşma sonrası anlaşmaya bağlılıkları konusunda belirleyici olabilir. Ceza ekonomik baskıdan askeri güç kullanımına kadar pek çok yaptırım, zorlama ve tehdit unsurunu içine almaktadır (Yıldırım, 2015, s. 128).

Zartman ve Touval, arabulucuyu "iletişim sağlayan kolaylaştırıcı, formüle edici ve manüplatör” olmak üzere üç türe ayırmaktadır. İletişim sağlayan kolaylaştırıcı daha çok sosyolojik yöntemlere başvurmaktadır. Formüle edici iki tarafın üzerinde anlaşabileceği formüller bularak öneriler getirmektedir. Manipülatör ise sadece planlama yapmaz, anlaşmanın kabulü için taraflara baskı uygulayabilmektedir (Zartman ve Touval, 2007, s. 437-444). İletişim sağlayan ve kolaylaştırıcı arabuluculuk görece daha yumuşak bir üçüncü taraf rolü iken manüpülatör arabuluculuk baskı, zorlama stratejileri kapsayan üçüncü taraf rolüdür (Gartner, 2014, s. 201-220).

Kressel sözleşmeli ve acil olmak üzere iki türlü bir arabuluculuk kategorizasyonu yapmıştır. Sözleşmeli arabuluculukta, arabulucu taraflara yardım etmek için dışarıdan gelen, taraf olmayan aktörken, acil arabulucu çıkarlarına istinaden sürece müdahil olup, çözüme katkı sağlamaya çalışır (Kressel, 2006, s. 734-735). James Wall ve Kenneth Kressel yapısal, ilişkisel ve baskı yapan olmak üzere üç ayrı arabuluculuk kategorisi yapmaktadır. Wendy Betts'e göre arabulucu özellikle bir devletse uyuşmazlığın durumuna göre daha agresif ya da savunmacı olabilecektir. Bu çıkarım üzerinden saldırgan ve savunmacı arabulucu ayrımına gitmiş̧ir (Betts, 1999, s. 168). Defansif arabulucular bölgede ya da taraflar üzerinde güç, etki ve nüfuzlarını arttırmaya çalışılmakta, gerginliğin düşürülmesini amaçlamaktadırlar. Saldırgan arabulucular ise daha çok uyuşmazlığın kendilerine yansımasından endişe etmektirler. Bunlar da küçük ve orta ölçekteki devletlerdir (Betts, 1999, s. 168). Norveç gibi İskandinav ülkelerinin oynadıkları rol daha yumuşak ve tarafsız bir konumdadır. Bu yüzden kolaylaştırıcı arabulucu olarak değerlendirilebilirler (Çuhadar, 2007, s. 99). Bir ülkenin kendi çıkarı, güvenliği ve istikrarı tehlikeye girdiğinde arabuluculuğu daha aktif ve defansif olabilmektedir (Zartman ve Touval, 2007, s. 438; Altunışık ve Çuhadar, 2010, s. 388-389). Çatışma sonrası toplumlardaki uyuşmazlıklarda ilişkisel arabuluculuğun daha iyi sonuçlar aldığı iddia edilmektedir (Zenelaj, Beriker ve Hatipoglu, 2015, s. 5).

E.Çuhadar ve M. Altunışık Türkiye'nin Arap-İsrail uyuşmazlığındaki üçüncü taraf rolünü inceledikleri çalışmada T. Princen'e atıfla ilkesel güçlü arabulucu ile 
nötr kolaylaştırıcı arabulucu ayrımına gitmektedirler. İlkesel güçlü arabulucuların genelde uyuşmazlık konusunda doğrudan çıkarları ya da etkilendikleri bir alan olabilmektedir. Bu yüzden de masaya çözümlerle gelebilmektedirler. Nötr kolaylaştırıcı ise doğrudan çıkarı olmayan, çıkar gözetmeyen ya da ilgisi olamayan üçüncü taraf modelidir. İlkesel güçlü arabulucu, taraflardan birisi ile yakın ilişki içinde olabilir ve uyuşmazlığın diğer tarafları üzerinde baskı kurmak için farklı ödül ve ceza araçlarına başvurabilir. Nötr, yansız arabulucu ise uyuşmazlık konusunda kanal açıp tarafların çözümlerini kendilerinin bulmalarını sağlamaya çalışmaktadır. ${ }^{16}$ İlkesel güçlü arabulucunun da içinde olduğu güçlü arabulucuların kaynakları ile birlikte itici gücünün (leverage) olması gerekir. Leverage (itici güç, kaldıraç) arabulucuya hareket alanı vermenin yanında uyuşmazlık yaşayan tarafları yönlendirmeyi, ikna etmeyi de sağlamaktadır (Touval ve Zartman, 2001, s. 439). İtici güç, tarafları istenilen yöne çekebilme olarak da tanımlanabilir (Touval ve Zartman, 2001, s. 436). Ancak özellikle çatışma yaşayan tarafların keskinleştiği, beklentilerin yükseldiği ya da müzakereler sırasında gerilimin arttığı süreçlerde itici rolünün çok az ya da fazla olmasının olumsuz sonuçları olabilmektedir (Rothchild, 1997, s. 14). Tarafsızlık ve itici güç arasında önemli bir ilişki vardır; tarafsız bir arabulucunun itici gücü çok olmayabilir ancak, taraflı olan bir arabulucunun itici güç için daha çok irade göstermesi beklenilmektedir (Kleiboer, 1996, s. 372).

\section{Arabuluculukta Taraf - Güç İlişkisi}

Taraflı arabulucunun kabul gördüğü hatta daha etkili olduğu durumlardan bahsedilmişti. Uyuşmazlık yaşayan taraflardan birisinin arabulucunun diğer taraf ile kurduğu ilişki ya da tarihsel bağlarından dolayı ona karşı önyargılı olsa bile arabulucuyu kabul edebildiğine değinilmişti. Arabulucuya karşı mesafeli ya da ön yargılı bir bakış olmasına rağmen kabul edilmesi arkasında arabulucunun uyuşmazlığın çözümüne dönük olası katkıları, sunduğu çözüm ve tarafların beklentilerini karşılayıp karşılamamaları vardır. Burada da arabulucunun çatışan tarafların çıkarlarını koruyabilecek olması, onlar üzerindeki etkisi, güç potansiyeli, onlara uygulayacağı baskı ya da sunacağı ödüller çok etkilidir (Touval ve Zartman, 2007, ss. 339-341) Bu duruma binaen güce ve imkanlara sahip bir arabulucunun taraf olmasının ya da arabulucuya dönük önyargıların olmasının, sürecin devamı açısından olumsuz yönde çok etkisi olmadığı yönünde geniş bir literatür bulunduğu hatırlatılmalıdır. Ancak belirtmek gerekir ki, uyuşmazlık yaşayan taraf ile aynı değerleri paylaşan; ideolojik, kültürel, siyasi yakınlık ve iş birliği olan üçüncü taraf daha etkili olmaktadır. Bu bakış açısını savunan J. Bercovitch ve G. Schneider ideolojik yakınlık, kültür ve coğrafyanın da arabuluculukta etkili olduğunu belirtmektedirler (Bercovitch ve Schneider, 2020, s.148-156).

16 Principle (ilkesel) arabulucu bazı kaynaklarda güçlü, neautral (yansızlık) arabulucu ise kolaylaştırıcı olarak yorumlanabilmektedir(Altunışık ve Çuhadar, 2010, s. 378). 
Taraf güç ilişkisindeki bir başka nokta ise büyük güçlerin, orta büyüklükte güçlerin ya da küçük güçlerin yaklaşımlarıdır. Büyük güçlerin arabuluculuğu sıkça görünür bir durumdur. Örneğin ABD 1945’ten bu yana çok aktiftir (Touval, 1992, s. 232-248). Keza Soğuk Savaş döneminde SSCB'nin de sıklıkla arabuluculuk yaptığı görülmüştür. ABD arabuluculuğu bir taraftan küçük devletlerin kendi politikalarına angaje olmaları yönünde bir araç olarak da kullanmaktadır. Hatta küçük devletler, desteğini alabilmek için de ABD’yi arabulucu olarak davet edebilmektedir.

Orta büyüklükte güçler lider olmak, bölgelerinde düzen ve istikrarı sağlamak ya da bölgenin gücü, istikrar ve düzen unsuru olduklarını göstermek için hareket edebilirler. Orta büyülükte güç veya bölgesel güçler etki alanları arayışı ya da olan etki alanını arttırma, prestiji, çatışmanın yayılma ihtimalinin bölgesel güçlerine tehlike oluşturabilmesi, iç etkenler, çıkar ilişkisi ile çerçevesinde uyuşmazlık çözümüne başvurulabilirler (Zartman ve Touval, 2007, s. 446-451). Arabuluculuk, orta büyülükte güçlere hem bölgelerinde hem de uluslararası ilişkilerde normalde sahip olamayacakları bir alan açmaktadır. Açılan alan hem iç politikada hem de dış politikada ilgili ülkeye güç, imkân ve opsiyonlar vermektedir. Uyuşmazlıkları tam olarak çözemese bile bu durum, ilgili devlete ittifak ilişkilerinden iç politikasına, diğer devletlerle olan ilişkilerinden dış politika görünürlüğüne kadar pek çok konuda yeni olanaklar açmaktadır. Yani arabuluculuk ekstra bir güç ve hegemonya inşası sağlayabilmektedir (Beriker, 2007, s. 431).

Literatürde küçük devletler ise hegemon, büyük güç ya da süper güçlerin aksine zorlama araçları kullanmadan, sürecin içinde doğrudan çıkarı olmayan ve taraf olmayan, daha çok psikolojik ve fiziksel destek sağlayan, iletişim kanalları açan devletler olarak değerlendirilmektedir. Ancak bu durumun aksine çıkarı olup da bunu perdeleyen örnekler de görülebilmektedir. Küçük devletlerin sınırlı imkânları arabuluculukta dezavantajlı görülseler bile kimi zaman büyük güçlere oranla daha avantajlı bile olabilirler (Williams, 1992, s. 52-64; Federal Foreign Office \& Initiative Mediation, 2017, s. 1-4).

\section{Arabuluculuk Konusunda Diğer Noktalar}

Literatürün önce gelen isimlerinden olan Jacop Bercovitch ve Richard Jackson’a (2020) göre arabuluculuk girişimi "taraflar, uyuşmazlığın nedenleri ve doğası, arabulucu ve bağlam” olmak üzere dört asli unsura dayanmaktadır: ideal bir arabulucunun bu dört asli unsuru çok iyi analiz etmesi gerekmektedir (Bercovitch ve Jackson, 2020, s.70).

Arabuluculuğun başarısı tartışmalı bir konudur. Kimi uzmanlar süreci başlatmayı bile başarı olarak nitelendirirken kimi uzmanlar arabuluculuğun başladığı nokta ile karşılaştırma yapmaktadır (Yıldırım, 2015, s. 146). Hangi tür arabuluculuğun daha başarılı olduğu meselesinin yanıtı hala net değildir (Sevensson, 2009, 
s. 253). M. Kleiboer yapısal faktörlerin belirleyici olduğunu savunurken (Kleiboer, 1996, s. 360-389), Bercovitch ve Schneider entelektüel birikimi, enerjiyi, karşıyı anlamayı, sabrı ön plana çıkarmaktadır. Literatürde güven verme, kredi sahibi olma, kabul edilebilir olma, güç, kişisel ilişkiler taraf vs. tarafsızlık ilişkisi, süreci yönetebilme, ödül ve ceza gibi ögelerin başarısı üzerine analizler yapılmaktadır(Bercovitch ve Schneider, 2020, s.148-149). Ancak başarıdan kasıt sonuca ulaşmak ise arabuluculuğun başarısının belirlenmesinde uyuşmazlığın karakteri, tarafların çıkarları, tutumları ve taraflar arası ilişkiler, arabuluculuğun karakteri ve uluslararası konjonktür etkili olmaktadır (Kleiboer, 1996, s. 360-389). Arabuluculuğun başlatılması gereken dönem genelde çatışmaların çatışan tarafları için karşılıklı maliyet yüklediği, iki tarafın da kazanamadığı zamanların ideal dönem olduğu söylenebilir.

Devletlerin yaşanan bir uyuşmazlığın çözümüne dönük arabuluculuk girişimlerinin nedenleri arasında iç etkenlerden dış politika stratejilerine farklı saikler vardır (Touval, 2003, s. 91). ${ }^{17}$ Arabuluculuğun saiklerinin arkasında çok fazla değişken olabileceğinden, arabuluculuğu tek bir değişken üzerinden açıklanmasının eksik olacağı düşünülmektedir. Bu faktörlerden bir ya da birkaçı daha ön plana çıkabilir ya da ilgili faktörler birbirlerinin tamamlayıcısı olabilir. ${ }^{18}$

Arabulucular her ne kadar uyuşmazlığın olumsuz yansımalarından korunmak, etki ve nüfuzlarını attırmak ve güç olmayı amaçlasalar da kimi zamanlarda uyuşmazlığı uzatabilirler. Bu uzatma sürecin yanlış yönetimi ile ilgili olabileceği gibi arabulucunun süreç aracılığı ile tarafları kontrol edebilmesi, onları yönetebilmesi, ilgili yerde güç sahibi olabilmesi temelinde de yapılabilmektedir.

\section{Sonuç}

Uyuşmazlık yaşayan tarafların sorunlarının çözümsüz kaldığında üçüncü bir tarafın müdahil olması gerekebilir. Üçüncü tarafın rolü iletişim kanalları açmaktan, hukuksal mekanizmalara ve fiziksel müdahaleye kadar geniş bir yelpazeyi kapsamaktadır. Arabuluculuk da bu üçüncü taraf rollerinden birisidir.

17 Devletlerin arabuluculuk ya da kolaylaştırıcılık gibi üçüncü taraf rollerinin nedenlerine ve türlerine bakıldığında farklı yaklaşımlar olduğu görülmektedir. Yaşanan uyuşmazlığın kendisinin güvenliğini olumsuz etkileyebilecek olması ihtimalini önlemek ve uyuşmazlığın yaratacağı düzensiz göç ve istikrarsızlığın kendisine dönük muhtemel yansımalardan duyulan endişelerin önüne geçmek için arabuluculuk yapılabilir. Arabuluculuk; uyuşmazlık yaşayan aktörler üzerinde etki ve nüfuza sahip olmayı, iyi ilişkilere sahip olmayı da sağlamaktadır. Dolayısı ile etki ve güce sahip olmak için de arabuluculuk yapılabilir. Ayrıca devletlerin barışın inşasına yapacakları katkılar, onların uluslararası alandaki imajlarını, kabul edilirliklerini ve saygınlıklarını da etkileyebilmektedir. Arabuluculuk, iç politikayı dönüştürme ve konsolide etme yönünde etkilediği gibi iç politikanın bir yansıması olarak da ortaya çıkabilmektedir.

$18 \mathrm{Bu}$ noktada da güvensizlik, göç, istikrarsızlık gibi çatışmanın olumsuzluklarının önüne geçmenin yanında nüfuz sağlama, taraflar üzerinde etkiye sahip olma, güç, prestij, iç etkenler, kabul edilme gibi temel nedenler arabuluculuğun motivasyonu olabilmektedir. 
Literatürdeki tartışmalardan görüleceği üzere arabuluculuğun türü, yöntemi ve stratejileri ile ilgili geniş bir literatür bulunmaktadır. Bu çalışmada arabulucunun taraflı ve tarafsız olması ile gücü ve etkileri üzerine odaklanılmışır. Geleneksel uluslararası ilişkiler ve hukuk yaklaşımlarında ideal arabulucunun tarafsız olması gerektiği iddia edilmiş olsa da Uyuşmazlık Analizi ve Barış Çalışmalarını da kapsayan yeni yaklaşımlarda taraf ve tarafsızlık ilişkisi yeni bir perspektifle ele alınmıştır. Bu çalışmada literatürdeki geniş ve derin tartışmalara da atıfla arabuluculuk güçlü taraflı ile tarafsız ve güçlü olmayan ikiliği üzerinden incelenmiştir.

Arabulucunun tarafsız olması gerektiğini savunan yaklaşımlar, tarafsızlığın uyuşmazlık yaşayan/çatışan tarafların güven duyması, kabul etmesi ve rıza göstermesi bakamından hayati öneme sahip olduğunu savunurlar. Aslında bu iddia ideal bir arabuluculuk önerisi yapması bakımından önemlidir. Tarafsız arabulucular daha çok küçük devletler, uluslararası örgütler, yaşanan uyuşmazlıktan doğrudan etkilenmeyen ya da bölgesel/küresel hegemonik iddiası olmayan devletlerdir.

Taraflı bir arabulucuyu savunanların argümanları ise tarihsel ve politik ilişkileriyle uyuşmazlığın taraflarını etkileyebilecek, çözüme ikna edecek olmasına odaklanmaktadır. Arabulucunun taraflı olmasından ziyade sürece sunduğu katı ve taraflarla kurduğu ilişkiye odaklanılır. Burada da taraflı olmanın sınırları ve dengesi olmalıdır denilmektedir. Bir aktöre daha yakın taraflı olarak nitelenen bu arabulucular daha çok güçlü devletler, sorundan doğrudan etkilenen ülkeler, eski sömürgeler olabilmektedir.

Farklı çatışma bölgelerinde yapılan arabuluculuk girişimleri ve literatür tarandığında çalışmada bazı çıkarımlara ulaşılmıştır. Arabulucunun taraflı ya da tarafsız olmasından ziyade yaklaşımı önemlidir. Arabulucunun tarafsız olması en ideal durumdur, ancak bir tarafa görece daha yakın olan taraflı bir arabulucu, süreci yönetirken taraf/tarafsızlık dengesini iyi kurması, sahip olduğu olanaklar, ödül ve ceza yöntemi ile uyuşmazlığın tıkanan yerlerini açabilir, çatışan tarafları ikna edebilir. Yani burada bir aktöre yakın olsa bile diğer aktöre adil ve ölçülü yaklaşması, diğer aktörün güvenini kazanması bakımından önemlidir. Burada altı çizilmesi gereken nokta arabulucunun getirdiği öneriler, süreç yönetimi, aktörler arasında kurduğu dengeyle birlikte tarafları "ikna" edebilmek için sunacağı şeylerdir. Bu bazen ekonomik ve politik ödüller olacağı gibi bazen de kuvvet kullanma, ekonomik yaptırımlar, politik baskılar, karşı tarafı desteklemeye kadar uzanan zorlamamalar (ceza) olabilir. Dolayısıyla tam tarafsız olmasa bile arabulucunun hegemonik gücü, ekonomik ve politik imkanları sürecin yönetilmesi bakımından hayati öneme sahiptir. Bu ülkeler daha çok büyük güçlerdir.

\section{Kaynakça}

Altunışık, M. ve Çuhadar, E. (2010). Turkey’s Search for a Third Party Role in ArabIsraeli Conflicts: A Neutral Facilitator or a Principal Power Mediator?. Mediterranean Politics, 15(3), 371-392. 
Beardsley, K.C., Quinn, D.M., Biswas, B. ve Wilkenfeld, J. (2006). Mediation Style and Crisis Outcomes. Journal of Conflict Resolution, 50(1), 58-86.

Bercovitch, J. , Anagnoson, J.T. ve Wille, D.L. (1991). Some Conceptual Issues and Empirical Trends in the Study of Successful Mediation in International Relations. Journal of Peace Research, 28(1), 7-17.

Bercovitch, J. ve Jackson, R. (2020). Yirmi Birinci Yüzyılda Çatışma Çözümü, İlkeler, Yöntemler ve Yaklaşımlar. (Çev. Hayrettin Özler). Ankara: Adres.

Bercovitch, J. (2002). Studies in International Mediation. New York: Macmillian, 2002.

Bercovitch, J. ve Derouen Jr. (2004). Mediation in Internationalized Ethnic Conflicts: Assessing the Determinants of a Successful Process. Armed Forces \& Society, 30(2), 147-170.

Bercovitch, J. ve Fretter, J. (2007). Studying International Mediation: Developing Data Sets on Mediation, Looking for Patterns, and Searching for Answers. International Negotiation, 12(2), 145-173.

Bercovitch, J. ve Schneider, G. (2000). Who Mediates? The Political Economy of International Conflict Management. Journal of Peace Research, 37(2), 145-165.

Bercovitch, J. (1992). The Structure and Diversity Of Mediation in International Relations, J. Bercovitch ve J. Rubin (Ed.), Mediation in International Relations: Multiple Approaches To Conflict Management (s. 10-21) içinde. Londra: MacMillan,

Beriker, N. (2014). Introduction the FPC-TR Dataset: Dimensions of AK Party Foreign Policy. Insight Turkey, 16(3), 201-217.

Beriker, N. (2017). Mediation as Politics: How Nations Leverage Peace Engagements?. International Negotiation, 22(3), 431-450.

Betts, W. (1999). Third Party Mediation: An Obstacle to Peace in Nagorno Karabakh. SAIS Review, 19(2), s.161-183.

Çelik, N. (2015). The Intentions and Capabilitites of Turkey as a Regional Power: Structual Analyses (2002-2014), Kadir Has Üniversitesi, Sosyal Bilimler Enstitüsü Yayınlanmamış Doktora Tezi, İstanbul.

Çuhadar, G. E. (2007). Turkey as a Third Party in Israeli-Palestinian Conflict: Assessment and Reflections. Perceptions, Bahar, 89-108.

Çuhadar G. E. (2009). Çatışma Ortamında Üçüncü Tarafların Uzlaştırma Amaçlı Müdahaleleri: Paralel Diplomasiye Eleştirel Bir Bakış. N. Beriker (Ed.), Çatışmadan Uzlaşmaya Kuramlar, Süreçler ve Uygulamalar (s. 129-160) içinde. İstanbul: Bilgi Üniversitesi Yayınları.

Duursma, A. (2014). A Current Literature Review of International Mediation. International Journal of Conflict Management, 25(1), 81-98.

Fisher, R. J. ve Keashly, L. (1991). The Potential Complementarity of Mediation and Consultation within a Contingency Model of Third Party Intervention. Journal of Peace Research, 28(1), 29-52.

Fisher, R. J. (2001). Methods of Third-Party Intervation, N. Ropens, M. Fischer ve E. Manton (Ed.), Bergh of Handbook for Conflict Transformation (s.1-27) içinde. Berlin: Berg of Center for Conflict Management.

Frazier, D. V. ve Dixon, W. J. (2007). Third Party Intermediaries and Negotiated Settlements, 1946-2000. International Interactions, 32(4), 385-408.

Gartner, S.S. (2014). The Influence of Directive Strategies on Settlement Duration. International Negotiation, 19(2), 201-220.

Goetschel, L.(2011). Neutrals as Brokers of Peacebuilding Ideas?. Cooperation and 
Conflict, 46(3), 312-333.

Greig, M. J. ve Diehl, P. F. (2012). International Mediation. Cambiridge: Polity, 2012.

Jeong, H. (2009). Conflict Management And Resolution An Introduction. New York: Routledge.

Jönsson, C. (2000). Bargaining, Negotiation and Diplomacy: A Research Overview, W. Carlnaes, T. Risse ve B. Simmons (Ed.), Handbook of International Relations (s.379400) içinde. Londra: SAGE.

Keashly, L. ve Fisher, R. (1996). A Contingency Perspective on Conflict Interventions: Theoretical and Practical Considerations. J. Bercovitch (Ed.), Resolving International Conflicts: The Theory and Practice of Mediation (s. 235-261) içinde. Boulder: Lynne Rienner Publishers.

Keskin, F. (2009). Darfur: Koruma Yükümlülüğü ve İnsancıl Müdahale Kavramları Çerçevesinde Bir İnceleme. Uluslararası İlişkiler, 6(21), 67-88.

Kiraz, S. (2020). Uluslararası Arabuluculuğa Dair Değişen Yaklaşımlar ve Türkiye'nin Arabuluculuğun Dönüşümündeki Rolünün İncelenmesi. Akdeniz Üniversitesi İktisadi ve İdari Bilimler Fakültesi Dergisi, 20(2), 227-238.

Kleiboer, M. (1996). Understanding Success and Failure of International Mediation. Journal of Conflict Resolution, 40(2), 360-389.

Kressel, K. (2006). Mediation Revisited. P. T. Coleman, M. Deutsch ve E. C. Marcus (Ed.), The Handbook of Conflict Resolution Theory and Practice (s. 726- 748) içinde. San Francisco: CA Jossey- Bass.

Kriesberg, K. (1996). Varierties of Mediating Activities and Mediators in International Relations. J. Bercovitch (Ed.), Resolving International Conflicts: The Theory and Practice of Mediation, Londra: Lynne Rienner.

Kydd, A. (2003). Which Side Are You On? Bias, Credibility and Mediation. American Journal of Political Science, 47(4), 579-611.

Mayer, B. (2004). Beyond Neutrality: Confronting the Crisis in Conflict Resolution. San Francisco: Josey-Bass.

Hugh,M., Ramsbotham, O. ve Woodhouse, T. (2007). Contemporary Conflict Resolution: The Prevention, Management and Transformation of Deadly Conflicts. Cambridge: Polity.

Moore, C. W. (2003). The Mediation Process: Practical Strategies for Resolving Conflict. San Francisco: Jossey-Bass.

Pazarcı, H. (2004). Uluslararası Hukuk. Ankara: Turhan.

Powell, J. (2014). Teröristlerle Konuşmak, Silahlı Çatışmalar Nasıl Sona Erdirilir? (Çev. Nuray Önoğlu). İstanbul: Aykırı Yayınları.

Rothchild, D. (1997). Ethnic Bargaining and the Management of Intense Conflict. International Negotiation, 2(1), 1-20.

Sak, Y. (2015). Uluslararası Hukukta İnsancıl Müdahale ve Libya Örneği: Suriye'de Yaşanan ya da Yaşanacaklar için Dersler. Uluslararası İlişkiler, 11(44), 121-153.

Savun, B. (2008). Information, Bias and Mediation Success. International Studies Quarterly, 52(1), 25-47.

Sevensson, I. (2009). Who Brings Which Peace?: Neutral versus Biased Mediation and Institutional Peace Arrangements in Civil Wars. The Journal of Conflict Resolution, 53(3), 446-469.

Smith, W. P. (1985). Effectiveness of the Biased Mediator. Negotiation Journal, 1, 363-372. Snodderly, D.(Ed.). (2011). Peace Terms, Glossary of Terms for Conflict Management and 
Peacebulding. Washington DC: United States Institute of Peace Washington.

Stedman, S. J. (1999). Negotiation and Mediation in Internal Conflict. M. Brown (Ed.), The International Dimensions of Internal Conflict (s. 369-371) içinde. Cambridge: MIT Press.

Svensson, I. (2006). Elusive Peacemakers: A Bargaining Perspective on Mediation in Internal Armed Conflicts, Uppsala: Uppsala University.

Şahin, Y. (2012). Kimlik Temelli Çatışmalar ve Barış Arayışları: Kıbrıs ve Lübnan'ın Analizi, Ankara Üniversitesi Sosyal Bilimler Enstitüsü Yayınlanmamış Yüksek Lisans Tezi, Ankara.

Şahin, Y. (2020). Türkiye’nin Barış Politikası, F. Köksoy (Ed.), Küresel Politikalar Ve Bölgesel Dönüşümler (s. 259-303) içinde. Ankara: Nobel.

Touval, S. ve Zartman, W. (1985). Introduction: Mediation in Theory, S. Touval ve W. Zartman (Ed.), International Mediation in Theory and Practice (s. 7-17) içinde. Boulder: CO Westview Press.

Touval, S. (2003). Mediation and Foreign Policy. International Studies Review, 5(4) 91-95.

Touval, S. (1992). The Superpowers as Mediators, J. Bercovitch ve J. Z. Rubin (Ed.), Mediation in International Relations: Multiple Approaches to Conflict Management (s. 232-248) içinde. New York: St. Martin's.

Touval, S. ve Zartman, I. W. (1989). Mediation in International Conflicts. K. Kressel, D. G. Pruitt (Ed.), Mediation Research (s. 15-37) içinde. San Francisco: Jossey-Bass Publishers.

Touval, S. (1992). The Superpowers as Mediators, J. Bercovicth ve J.Z. Rubin (Ed.), Mediation in International Relations: Multiple Approaches to Conflict Management (s.232-248) içinde. New York: Macmillian/St Martisn’s Press.

Touval, S. ve Zartman, W. (2001). International Mediation in Post-Cold War Era. C.A. Crocker, F. O. Hampson ve P. Aall (Ed.), Trubulent Peace-The Challanges of Managing International Conflict (s. 427-443) içinde, Washington DC: United States Institute of Peace.

Wall, J. ve Kressel, K. (2012). Research on Mediator Style: A Summary and Some Research Suggestions. Negotiation and Conflict Management Research 5(4), 403-421.

Wallensteen, P. (2007). Understanding Conflict Resolution. War, Peace and the Global System. Londra: SAGE.

Williams, A. (1992). Mediation by Small States: Some Lessons from the CSCE, Paradigms, 6(1), 52-64.

Yıldırım, F. (2015). Bölgesel Arabuluculuk Faaliyetleri: Türkiye Örneği, Kara Harp Okulu Savunma Bilimleri Enstitüsü Yayınlanmamış Doktora Tezi, Ankara.

Yılmaz, M. E. (2005). Uyuşmazlık Analizi ve Çözümü, İnsan Uyuşmazlıklarının Kaynakları ve Çözüm Paradigmaları. Ankara: Nobel.

Young, O. R. (1967). Intermediaries: Third Parties in International Crises. Princeton: Princeton University Press.

Zartman, I. W. (2001). Negotiating Internal Conflict: Incentives and Intractability. International Negotiation, 6(3), 297-302.

Zartman, I.W. ve Touval, S. (2001) International Mediation in the Post Cold War Era, C.Crocker, F. Hampson ve P. Aall (Ed.), Turbulent Peace (s. 427-443) içinde. Washington DC: United States Institute of Peace.

Zartman, W. I. (2013). Mediation Roles for Large Small Countries. Canadian Foreign Policy Journal, 19(1), 13-25. 
Zartman, W. ve Touval, S. (2007). International Mediation in the Post Cold War Era, C. A. Crocker (Ed.), Leashing the Dogs of War: Conflict Management in a Divided World (s. 437-444)içinde, Washington DC: United States Institute of Peace Press.

Zartman, W. (2008). Negotiation and Conflict Management: Essays on Theory and Practice. Abingdon: Routledge.

Zenelaj, R. Beriker N. ve Hatipoğlu, E. (2015). Determinants of Mediation Success in Post-Conflict Bosnia: a Focused Comparison. Australian Journal of International, 69(4), 414-437.

\section{İnternet Kaynakları}

“Uyuşmazlıkların Çözümü ve Arabuculuk”, Dışişleri Bakanlığı, http://www.mfa.gov.tr/ uyusmazliklarin-cozumu-ve-arabuluculuk.tr.mfa

BM Kararı, Birleşmiş Milletler

https://peacemaker.un.org/sites/peacemaker.un.org/files/GARes_StrengtheningT heRoleOfMediation_ARES65283\%28english\%29_0.pdf (erişim tarih 17.03.2021)

Birleşmiş Milletler Etkili Arabuluculuk Rehberi, Dışişleri Bakanlığı, http://www.mfa.gov.tr/site_media/html/BM_Etkin_Arabuluculuk_Rehberi_Turkce.pdf (erişim tarih 17.03.2021)

Koopmans, S. M. (2018). Negotiating Peace, A Guide to Pratice, Politics, and Law of International Mediation, Oxford: Oxford University Press .

http://abfifer.com/blog/2010/08/partisan-arbitrators/ (erişim tarihi 20.04.2021)

TheRolesandContributions ofStatesinPeaceMediationFactSheetSeries:PeaceMediationand Mediation Support. Federal Foreign Office \& Initiative Mediation, Berlin, 2017, https:// www.auswaertigesamt.de/blob/1993530/684b34753d9fc5a28137d021eb39a956/ roles-of-states-in-peace-mediation-data.pdf (erişim tarihi 20.04.2021)

Dizdaroğlu, C. (2019). Çatışma Çözümü. Güvenlik Yazıları Serisi, No.19. https:// trguvenlikportali.com/wp-content/uploads/2019/11/CatismaCozumu_ CihanDizdaroglu_v.1.pdf(erişim tarihi 20.04.2021) 